\title{
Assessing the "Good Life" in a Military Context How Does Life and Work-Satisfaction Relate to Orientations to Happiness and Career-Success Among Swiss Professional Officers?
}

\author{
Journal Article \\ Author(s): \\ Proyer, René T.; Annen, Hubert; Eggimann, Nadine; Schneider, Andrea; Ruch, Willibald \\ Publication date: \\ 2012-05 \\ Permanent link: \\ https://doi.org/10.3929/ethz-b-000047848
}

Rights / license:

In Copyright - Non-Commercial Use Permitted

Originally published in:

Social Indicators Research 106(3), https://doi.org/10.1007/s11205-011-9823-8 


\title{
Assessing the "Good Life" in a Military Context: How Does Life and Work-Satisfaction Relate to Orientations to Happiness and Career-Success Among Swiss Professional Officers?
}

\author{
René T. Proyer $\cdot$ Hubert Annen • Nadine Eggimann • \\ Andrea Schneider • Willibald Ruch
}

Accepted: 27 February 2011/Published online: 6 March 2011

(C) Springer Science+Business Media B.V. 2011

\begin{abstract}
The study examines work- and life satisfaction along with orientation to happiness, and their relation to subjective but also objective career success, among Swiss military professional officers. They frequently report worsening of their working conditions due to two reforms that have recently been conducted. A total of $N=221$ Swiss career officers (mainly Land Forces; from Colonel to First Lieutenant) completed several questionnaires in an online survey. As expected, pleasure, engagement and meaning were positively related to satisfaction with life and the meaningful life also correlated with the (overall) work satisfaction. Higher subjective career success was related to higher satisfaction with life, content-related aspects of work satisfaction, and higher endorsements to the engaged and the meaningful life. Belonging to the general staff was considered as an objective criterion of career success and those who were in the general staff, were higher in their overall work satisfaction, content-related aspects of their work and, again, higher inclination to the life of engagement and the life of meaning. The study suggests that variables of positive psychological functioning are useful additions in the field of military psychology and that they might hold a key for the development of strategies for improving both, work- and life satisfaction among military personnel.
\end{abstract}

Keywords Engagement - Life satisfaction · Meaning · Military psychology · Pleasure · Work satisfaction

\section{Introduction}

This study examines positive psychological functioning within the context of military psychology. The good life is studied here in a very specific environment-i.e., in an

R. T. Proyer $(\bowtie) \cdot$ A. Schneider · W. Ruch Section on Personality and Assessment, Department of Psychology, University of Zurich, Binzmühlestrasse 14/7, 8050 Zurich, Switzerland e-mail: r.proyer@psychologie.uzh.ch

H. Annen · N. Eggimann

Military Academy at ETH Zurich, Zurich, Switzerland 
institution that fosters and cultivates values. This institution expects its members to engage in strengths like courage, respect, or responsibility and it is associated in societies with values such as (national) security and tradition. A few peculiarities of the Swiss military system should be highlighted for a general understanding of the sample that is to be studied (see also Annen et al. 2010). Switzerland has a militia-system of a compulsory military service in which all Swiss males aged between 19 and 31 must serve. The basic training lasts between 18 and 21 weeks followed by three weeks of training per year until the age of 26. Females may join the Forces voluntarily; all groups including combat troops. Alternatively to the military service, males may chose to serve in Civil Protection or Civilian Service (i.e., weaponless services). The main tasks of the Swiss Army are of defensive and protective nature and it serves in case of natural catastrophes and related fields. A characteristic feature of the Swiss Armed Forces is that the majority of officers are members of the militia. Accordingly, career officers as well as contracted military personnel account for only about $3 \%$ of the total Swiss Armed Forces (Annen 2004). These career personnel serve important functions such as educators and instructors or rather as coaches of the militia cadre and are responsible for the molding of a leadership culture as well as the implementation of certain guidelines.

In 1995 and in 2004, ballots in Switzerland favored major reforms in the Armed Forces. These reforms led to a reduction of the size of the Swiss Armed Forces and to cuts in the budget of the Federal Council ("Federal Department of Defence, Civil Protection and Sports"). From the viewpoint of personnel this reform was related to a decline in the working conditions. Additionally, there are further job-specific characteristics that need to be considered when thinking of the well-being of the officers (e.g., specific challenges of the actual mission). Furthermore, the reputation of the Swiss Army has suffered among the general public in the last years due to several incidents that have been picked up extensively by the press (e.g., allegations of sexual harassments for one of the highest ranked officers and fatal casualties at training camps). These and other factors led a steadily increasing number of dismissals of career officers. Nevertheless, Gutknecht (2007) reports quite a high level of work satisfaction among the military personnel of the Swiss Armed Forces (in comparison to a professional group of IT specialists), whereas the organizational commitment appears to be mediocre. Therefore, it seems fruitful to study the actual expression of work and life satisfaction of Swiss career officers empirically.

While satisfaction with life and work has frequently been studied in the context of military psychology (e.g., Allen 2003; Hindelang et al. 2004; Sanchez et al. 2004; Wilcove et al. 2003), positive psychology provides the possibility to study subjective well-being in a more exhaustive way. Positive psychology is the scientific study of positive experiences and positive traits (cf. Seligman and Csikszentmihalyi 2000) and is a research area of growing interest within psychology. Studying the good life and factors that enable flourishing are the prime aims. According to Seligman (2002), there are three routes to happiness. Firstly, there is hedonism. Trying to achieve pleasurable experiences and avoiding harmful experiences is the main focus of the life of pleasure. Secondly, based on Csikszentmihalyi's works on the flow experience (e.g., Csikszentmihalyi 1990), Seligman concluded that being absorbed by an engaging activity leads to happiness (i.e., life of engagement). Thirdly, there is the idea of using ones strengths and talents, cultivating them, and living in accordance to them, which may also contribute to the good life (i.e., life of meaning - following an eudemonic principle as it has been already described by ancient philosophers such as Aristotle). In psychology, eudaimonic well-being, its origins, correlates and consequences, have also been studied widely (e.g., Ryan and Deci 2001; Sheldon 2002). 
Peterson et al. (2005) developed the Orientation to Happiness (OTH) scale that allows the subjective assessment of these three orientations by means of an economic, reliable (in terms of internal consistency and retest-reliability), and valid (by means of convergent, discriminant, construct, and criterion validity) 18 -item questionnaire. The three routes to happiness were empirically related (correlations between $r=0.17$ and $r=0.46, p<0.01$, for life of pleasure and life of meaning and life of engagement and life of meaning, respectively) but not interchangeable (see also Peterson et al. 2007). Furthermore, Peterson et al. (2005) reported that the pleasurable life was related to younger age, lower education, and not being married. In Peterson et al. (2005) and Peterson et al. (2007) as well as in Schueller and Seligman (2010), there were positive relations among the three orientations with satisfaction with life (highest among E and M). Ruch et al. (2010) replicated these findings with a German version of the scale. Results of the study showed that the selfreports on typical behavior in situations that were assigned to pleasurable, engaged, and meaningful situations were in the expected directions; i.e., highest correlations to the OTHscales in the homologous situations and lower (mostly non-significant) in heterologous situations.

Matthews et al. (2008) point out that the emergence of positive psychology comes at a time when military organizations are faced with a wide array of challenges and suggest areas of application of positive psychology, such as novel ways of training soldiers, treating those with psychological trauma and helping military families cope effectively with the deployment of their loved one(s). They argue that the military is a perfect "home" for positive psychology because it is composed of relatively young, healthy, and pathology-free individuals. Moreover, the military, with its strong emphasis on character development, morale, and welfare, can easily be construed as a positive institution. Considering Matthew et al.'s current suggestions it is assumed that there is a high interest within military psychology to implement those ideas. To our knowledge, there are no reports on orientations to happiness in a military context published so far. This first study should illuminate how variables of positive psychological functioning might contribute to different aspects of the work-life of career officers. For example, it is assumed that fostering an engaged life or finding meaning in one's life (or: work life) contributes (in this context) not only to the well-being and forthcoming of an individual, but a whole organization (in this case the Army) might benefit from leaders that take an engaged and meaningful stance towards life. If these variables, as expected, relate to subjective but also objective variables of career success, then this might also give rise to the idea of setting up training programs for engagement and meaning in the work context.

\subsection{Why Studying Orientations to Happiness Among Career Officers?}

Despite its novelty, there are a number of other reasons why this study might contribute to the knowledge in the field. Hitherto, relatively little information is available on how orientations to happiness relate to work satisfaction. One might argue that the pleasurable life should be less robustly related to satisfaction with work (as it may be rather distracting from work to pursue hedonism), but that the satisfaction of those, who can frequently experience flow while working, should increase. There is much literature on the positive impact of flowexperiences in the work-context; e.g., more flow-experiences are being reported while working as well as more positive experiences at work, positive mood or more innovation at work to name only a few (e.g., Csikszentmihalyi 1990; Csikszentmihalyi and LeFevre 1989; Eisenberger et al. 2005; Fullagar and Kelloway 2009; Nielsen and Cleal 2010). Thus, it seems to be fruitful to study whether working conditions of career officers allow the officers 
to experience an engaged life. In case the engaged life and work satisfaction do exist independently from each other, one might discuss precautions that may facilitate a change towards more flow-oriented activities (e.g., by restructuring duties or reduction of administrative load, etc.). However, it seems as if the life of meaning plays a more central role in the case of the military officers. The work-environment of a military officer almost per se fosters strengths like bravery, teamwork, leadership, perspective, or persistence. It is assumed that a person with a good fit to its environment should be able to experience meaning in his/her work. The basic idea is that people cultivate what is best in them and then use these strengths (or more generally spoken skills) for the good of something greater than themselves. Peterson et al. (2005) argue that the pursuit of a meaningful life allows an individual to connect to a greater good, which involves the provision of services for others. The latter seems to be of special relevance here as it was already argued that the prime aim of the military is providing service to the general public. The notion of the Swiss Army as an institution that facilitates positive meaning can even be found in the official service regulations of the Swiss Army ("Dienstreglement der Schweizerischen Armee 04", Schweizer Armee 2004; see also Annen et al. 2004).

This study examines whether those pursuing a meaningful life also experience higher work satisfaction. Thus, it is argued that both the engaged and the meaningful life contribute to work satisfaction, with the meaningful life being the primary contributor. Furthermore, it is assumed that those of higher rank can experience more meaning in their work, as they have more duties that should allow them to excel in this area. It is also assumed that there is a direct link from pursuing an engaged and meaningful life to objective indicators of career success. Thus, the idea is that those who experience flow while performing their duties and those who relate their work to the greater good, will not only perceive themselves as more successful but should also be seen as more successful as rated on more objective criteria. The later assumption is supported by a recently published study where both, engagement and meaning, were found to relate significantly to higher educational but also occupational attainment (Schueller and Seligman 2010). Overall, studying orientations to happiness with military personnel provides the possibility of examining the impact of the three orientations to happiness in a well-described and valueas well as virtue-related environment that could be seen as an organization that works for the greater good of a society.

Not only work- but also life-satisfaction is of interest in this context. Several earlier studies (e.g., Peterson et al. 2005; Peterson et al. 2007; Ruch et al. 2010; Schueller and Seligman 2010) have shown that orientations to happiness relate to life-satisfactionespecially engagement and meaning were found to be robustly related to well-being. This should not only be replicated for this sample but should also provide a deeper insight into the work environment of career officers. In case engaged officers and those pursuing meaning express higher satisfaction with their life, one might argue that specific working conditions (i.e., those that allow for experiencing flow and perceiving oneself as working for a greater good) have an impact on the subjective well-being of the career-officers, at least to a certain degree.

\subsection{Aims of the Present Study}

The present study has two main objectives. Firstly, we wanted to examine how variables of positive psychological functioning are interrelated among Swiss career officers. For example, whether a pleasurable, engaged, and meaningful life goes along with higher expressions in work and/or life satisfaction. It is argued that the Swiss Army should be a 
place where positive meaning is fostered. Therefore, one might expect that the meaningful life contributes to satisfaction with life but also to a higher satisfaction with work in general and the different aspects of one's own work (e.g., content-related aspects). The research concern the extent to which the pleasurable, engaged and meaningful life correlate with work satisfaction or satisfaction with life and whether these orientations to happiness have a potential for predicting satisfaction in these two areas?

Secondly, we examined how subjectively experienced success at work and an objective indicator of success at work (i.e., membership vs. non-membership to the general staff; see Gutknecht et al. 2005) were related to work and life satisfaction and the three orientations to happiness. Subjective ratings of success at work were also considered. It was expected that participants that described themselves with higher success at work would also be higher in work and life satisfaction. Furthermore, higher expressions in the engaged life were expected. Regarding the objective criteria, we expected higher expressions in the satisfaction with work as well as for the engaged and the meaningful life. Thus, the research question for the second aim is whether higher subjective and objective career success in officers of the Swiss Armed Forces go along with higher expressions in specific orientations to happiness and higher satisfaction with work and life. It is tested to what extent military career success relates with satisfaction with work and life and three orientations to happiness. Additionally, the data allow for testing further secondary research questions. For example, to what extent is military rank related to work satisfaction or satisfaction with life? Here, the expectation is that officers of higher rank are generally more satisfied than those of lower rank.

\section{Method}

\subsection{Research Participants}

The sample consisted of $N=221$ professional officers of the Swiss Army from Land and Air Forces. More than one third of the participants $(n=83)$ provided information on their assignment to one of the two groups. Practically all of those $(92.8 \%, n=77)$ were in the Land Forces-it is assumed that the distribution among those who did not provide information on their affiliation was highly similar. In the full sample, 218 were males, one was female and two did not provide information on their gender. Their age ranged between 25 and 58 years $(M=39.36 ; S D=8.68)$. More than a quarter $(28.96 \%)$ were Colonel $(M=49.35 ; S D=4.81), 23.08 \%$ were Lieutenant Colonel $(M=43.22 ; S D=5.18)$, $20.81 \%$ were Major $(M=34.65 ; S D=3.37), 26.70 \%$ were Captain $(M=30.29$, $S D=2.33$ ), and one was First Lieutenant (aged 25). About half $(n=106 ; 47.96 \%)$ belonged to the general staff, $108(48.87 \%)$ did not, and $7(3.17 \%)$ did not provide information on their status. The median of years in service was 8 years and ranged from first year (about 10\%) to 35 years (one person).

\subsection{Instruments}

The Orientation to Happiness measure (OTH; Peterson et al. 2005) is an 18-item selfreport questionnaire for the subjective assessment of life of pleasure, life of engagement, and life of meaning (six items each). It utilizes a 5-point Likert-scale ("1 = very much unlike me" through " 5 = very much like me"). A sample item for life of engagement (E) is "I am always very absorbed in what I do", for life of pleasure (P) "Life is too short 
to postpone the pleasures it can provide", and for life of meaning (M) a sample item is "I have a responsibility to make the world a better place". We used the German version of the OTH (Ruch et al. 2010). The reliability coefficients of the three scales were $\alpha=0.68$ $(\mathrm{P}), \alpha=0.69(\mathrm{E})$, and $\alpha=0.80(\mathrm{M})$, respectively. The OTH has been used in a broad rage of studies (also in its German form) and proved to be a valid and reliable measure (e.g., Chen et al. 2010; Park et al. 2009; Peterson et al. 2007; Proyer et al. in press; VellaBrodrick et al. 2009).

The Job Diagnostic Survey (JDS; Hackman and Oldham 1980; in the German adaptation by van Dick et al. 2001) assesses the subjective experience of objective work situations. Fpur items were employed to assess the general work satisfaction using a a 6-point answer format ranging from "strongly disagree" to "strongly agree". A sample item for general work satisfaction is "In general, I am happy with my work". 15 items were used to measure the content-related satisfaction with work. Job characteristics (diversity of requirements, task identity, interest, autonomy, chances for feedback) were assessed on a 6- and 7-point answer format, respectively, ranging from "strongly disagree" to "strongly agree". A sample item is "I perceive my work as very varied". Four items measured the resignative aspects of work satisfaction on a 6-point answer format ranging from "practically never" to "practically always". A sample item is "Even though my work is not ideal, it could be worse". The reliability of the three scales were between $\alpha=0.90$ (general work satisfaction), $\alpha=0.82$ (content) and $\alpha=0.85$ (resignation). The Germanlanguage version of the JDS proved to be useful within a military context in a recent study by Gutknecht (2007).

The Satisfaction with Life Scale (SWLS; Diener et al. 1985) is a five-item measure for assessing the satisfaction with life. A sample item is "The conditions of my life are excellent". It uses a 7-point answer form (from $1=$ "strongly disagree" through 7 = "strongly agree"). We used a German translation of the scale that proved its usefulness and good psychometric properties in previous studies (e.g., Peterson et al. 2007; Proyer et al. in press; Ruch et al. 2010; Ruch et al. 2010). The SWLS yielded a high internal consistency in the present sample $(\alpha=0.85)$. The SWLS is widely used and showed good psychometric properties in various studies (e.g., Diener 1994; Diener et al. 2000).

The Self-Estimated Career Success was measured by a single item; i.e., „How successful would you rank yourself as a Professional Officer in the Swiss Army?" Answers were given on a 5-point scale ranging from "not successful at all" to "very successful".

\subsection{Procedure}

Four hundred and fifty career officers (of German mother tongue) of the Swiss Army received an Email with an invitation to participate in an online survey (this is about $70 \%$ of the German speaking and $60 \%$ of the total number of career officers in the Swiss Army ${ }^{1}$ ). The message contained a link to the survey that was hosted by the University of Zurich. More than two thirds (70.4\%) of the career officers registered themselves for participation in a first step and received further information about the study (testing time, feedback procedure etc.). Finally, almost half of those who were initially invited completed the test

\footnotetext{
1 Switzerland has four official languages-namely, French, German, Italian, and Romansh. As a general guideline, it can be stated that German is spoken by more than two thirds of the population, French by a fifth and the rest Italian and Romansh, while the latter is only spoken by a small minority (less than one percent). In this first examination of the topic, we decided to focus on the officers of German mother tongue.
} 
battery (49.1\%). They completed all questionnaires along with a set of demographic variables online. The completion of the full study took about $45 \mathrm{~min}$. Using the Internet for data collection purposes has been criticized occasionally (e.g., for sample biases). However, we relied on standards that were set up for Internet-delivered testing (Coyne and Bartram 2006). Additionally, empirical studies suggest that data collected via the Internet lead to similar findings as more traditional methods of data collection (Gosling et al. 2004). Participants received a standardized and individualized feedback on their results after completion of the study.

\section{Results}

None of the variables that entered the study were significantly correlated with the number of years spent in duty (the median of all correlations was $r=0.02$ and ranged from $r=$ -0.10 [resignative aspects of satisfaction with work] to $r=0.13$ [content-related aspects of work satisfaction], all $p>0.05$ ). The impact of the rank was also tested. An ANOVA was conducted with satisfaction with life and work as dependent variable (all JDS-scales separately) and the rank as grouping variable (the one First Lieutenant was excluded from this analysis). In all analyses, only the content-related aspects of satisfaction with work yielded significant differences among the officers of different ranks $(F[3,222]=3.06$, $p<0.05)$. Here, Captains $(M=4.54, S D=0.50)$ scored lower than Colonels $(M=4.81$, $S D=0.56 ; d=0.51)$, Lieutenant Colonels $(M=4.74, S D=0.56 ; d=0.38)$, and Majors $(M=4.72, S D=0.44 ; d=0.38)$. Thus, officers of higher rank yielded lower satisfaction with the content-related aspects of work than those with lower rank. Apart from this finding, there were no further differences among the officers regarding life- or (specific aspects of) work-satisfaction.

Mean scores and standard deviations were computed for all scales that entered the study. The analysis of their skewness and kurtosis indicated normal distribution. However, the scores for the satisfaction with life indicated that the participants seemed to be rather satisfied with their lives. We computed correlations among all of the measures in order to answer the question on the relations among indicators of satisfaction with different areas of life and positive psychological functioning within the group of the career officers (see Table 1).

Table 1 shows that the correlation coefficients indicated that all three orientations to happiness were positively related to satisfaction with life. In a further analysis, satisfaction with life was used as the dependent variable in a multiple regression analysis. In this analysis, age (step 1) and the three OTH scales as predictors (method stepwise) yielded a multiple correlation coefficient of $.23(F[2,204]=5.83, p<0.01)$. In the final model, only the engaged life $(\beta=0.21)$ predicted satisfaction with life significantly, while, age did not reach statistical significance.

Table 1 shows further that out of the three orientations to happiness, only the life of meaning correlated significantly with the score for general work satisfaction and to the content-aspects of work. Both the engaged and the meaningful life contributed to work satisfaction. Satisfaction with life and work correlated in the expected range, indicating that they were related but not interchangeable. The same was true for the intercorrelation among the orientations to happiness scales. For the latter, however, it was striking that the relations between pleasure and meaning and engagement and meaning were higher than in other studies that used the German version of the OTH (Proyer et al. in press; Ruch et al. 2010). The inspection of a bivariate plot between these variables did not reveal any 
Table 1 Means, standard deviations, and intercorrelations for measures of life and work satisfaction and orientations to happiness in Swiss Army officers

\begin{tabular}{|c|c|c|c|c|c|c|c|c|}
\hline & $M$ & $S D$ & $W S$ & $C$ & $R$ & $P$ & $E$ & $M$ \\
\hline$S W L S$ & 5.30 & 0.96 & $0.45^{* *}$ & $0.41 * *$ & $0.35^{* *}$ & $0.15^{*}$ & $0.19 * *$ & $0.16^{*}$ \\
\hline$W S$ & 4.64 & 0.78 & & $0.63 * *$ & $0.60 * *$ & -0.03 & 0.12 & $0.18 * *$ \\
\hline$C$ & 4.70 & 0.53 & & & $0.49 * *$ & 0.06 & $0.28 * *$ & $0.22 * *$ \\
\hline$R$ & 5.60 & 1.34 & & & & -0.05 & 0.12 & 0.11 \\
\hline$P$ & 3.24 & 0.58 & & & & & $0.39 * *$ & $0.40 * *$ \\
\hline E & 3.40 & 0.58 & & & & & & $0.52 * *$ \\
\hline$M$ & 3.04 & 0.75 & & & & & & - \\
\hline
\end{tabular}

$N=221$

$M$ Mean, SD Standard deviation, SWLS Satisfaction with life, WS general work satisfaction, $C$ content of work, $R$ resignative aspects of work, $P$ Life of pleasure, $E$ life of engagement, $M$ Life of meaning

$* p<0.05 ; * * p<0.01$

peculiarities that might help explain the relation. Thus, the hedonic and engaged orientation to a good life seemed to have a higher association to a meaningful life among the Swiss career officers than in samples of Civilians. Again, a multiple regression was computed but this time with the total score for work satisfaction as dependent variable and the same predictors as in the previous analysis. The multiple correlation coefficient was $0.20(F[2,204]=4.26, p<0.05)$ and only the meaningful life was a significant predictor $(\beta=0.20)$.

\subsection{Relations to Career Success (Subjective)}

The relations to the subjectively estimated career success were based on the ratings of the single items included in the survey. The variable was slightly skewed $(S k=-1.03)$ as most of the participants described themselves as successful. Nevertheless, the data were normally distributed. We computed ANOVAs with three categories (not successful -as a composite of the two lowest answer categories, average success, successful-as a composite of the two highest answer categories) as grouping variable and satisfaction with life and work as well as the three orientations to happiness as dependent variables. Table 2 shows the mean scores for the three groups.

Table 2 shows that, overall, the variables discriminated well among the three groups. Subsequently conducted post hoc tests (LSD) showed that the successful officers showed higher satisfaction with life than any of the other groups ( $d=0.88$ compared to the unsuccessful group and $d=0.48$ in comparison with the averagely successful ones). Additionally, the group that described itself as averagely successful was more satisfied with life than the not successful officers $(d=0.45)$. Those who described themselves as most successful were more satisfied with their job than the averagely successful ones $(d=0.45)$ and the not successful ones $(d=0.83)$. This was also found for the two facets of work satisfaction that were covered in the present study. Higher self-ratings of career success went along with higher mean scores in content-related aspects of work in comparison to those who described average $(d=0.51)$ or no success $(d=1.16)$. The latter two groups also differed significantly from each other $(d=0.65)$. The same picture emerged for the degree of resignation experienced while working. The officers that experienced higher career success reported less resignation than any of the other groups $(d=0.28$ in 
Table 2 Mean score differences in satisfaction with work and life and orientations to happiness based on self-reported career success

\begin{tabular}{llllll}
\hline & No success & Average & Successful & F & $p$ \\
\hline$S W L S$ & $4.81^{\mathrm{ab}}$ & $5.29^{\mathrm{ac}}$ & $5.69^{\mathrm{bc}}$ & 7.71 & $<0.01$ \\
$W S$ & $4.34^{\mathrm{a}}$ & $4.61^{\mathrm{b}}$ & $4.97^{\mathrm{ab}}$ & 6.52 & $<0.01$ \\
$C$ & $4.38^{\mathrm{ab}}$ & $4.70^{\mathrm{ac}}$ & $4.96^{\mathrm{bc}}$ & 11.12 & $<0.001$ \\
$R$ & $5.06^{\mathrm{ab}}$ & $5.61^{\mathrm{a}}$ & $5.96^{\mathrm{b}}$ & 4.03 & $<0.05$ \\
$P$ & 3.32 & 3.21 & 3.29 & & 2.54 \\
$E$ & $3.32^{\mathrm{a} \dagger}$ & $3.37^{\mathrm{b}}$ & $3.57^{\mathrm{ab}}$ & 6.14 & $<0.10$ \\
$M$ & 3.19 & $2.93^{\mathrm{a}}$ & $3.35^{\mathrm{a}}$ & 6.14 & $<0.01$ \\
\hline
\end{tabular}

$N=221$ (no success: $n=30$, average: $n=150$, success: $n=41$ ). SWLS Satisfaction with life, WS general work satisfaction, $C$ content of work, $R$ resignative aspects of work, $P$ Life of pleasure, $E$ life of engagement, $M$ life of meaning

${ }^{\mathrm{a}-\mathrm{c}}$ Means sharing a superscript differ from each other significantly $\left({ }^{\dagger}\right.$ at $p<0.10$ )

comparison with the averagely successful and $d=0.71$ compared to the not successful ones). The officers with average success reported less resignation than the unsuccessful ones $(d=0.39)$.

The pleasurable life did not contribute to the discrimination of the groups, while, engagement and meaning did. However, the successful officers were higher in their endorsements of the engaged life (than both other groups; $d=0.47$ for no success and $d=0.09$ for average success; these differences need to be interpreted conservatively because of the comparatively low $F$-score) and in the meaningful life (than the average group; $d=0.59$ ). The average group was also higher than the no success group in the resignative aspects of their work but did not differ from the others in the overall work satisfaction.

\subsection{Relations to Career Success (Objective)}

Next to the subjectively estimated career success we also had information on whether the participants belong to the general staff as a more objective criterion for work success. We computed $t$-tests with 'belonging to general staff' as grouping variable ("yes" vs. "no") and the work and life satisfaction as well as orientations to happiness as dependent variables. Half the career officers who entered the study were members of the general staff $(n=106 ; 48.0 \%)$ and the other half were not $(n=108 ; 48.9 \% ; 7$ [3.2\%] did not answer this question). There were no differences in the satisfaction with life in the two groups $(t(212)=0.55, p>0.05)$. However, the members of the general staff described themselves as more satisfied with their work (total score; $t(212)=2.63, p<0.01 ; d=0.35$ ) and as happier with the content-dependent aspects of their work $(t(212)=3.67, p<0.001$; $d=0.50$ ); there were no differences in the resignative aspects of the work; $t(212)=1.62$, $p>0.05)$. Both groups described equal endorsement to the pleasurable life $(t(212)=$ $-0.40, p>0.05)$. However, the members of the general staff were higher in both, the engaged $(t(212)=2.33, p<0.05, d=0.32)$ and the meaningful life $(t(212)=2.58$, $p<0.05, d=0.35)^{2}$

\footnotetext{
${ }^{2}$ Belonging to general staff is, of course, not independently from the years spent in duty in the Army. Therefore, we also computed partial correlations between the belonging to general staff-variable and the variables involved in the mean comparisons, controlling for the years spent in duty. The results led to highly
} 
As a side note, it should be mentioned that the self-ratings of success at work and the objective indicator seemed to converge quite well as there were only twelve officers who saw themselves as not successful but were members of the general staff and there were fifteen who were not in the general staff but saw them as successful. Those two groups (i.e., the "wrongly classified") differed only in their satisfaction with life but none of the other variables that entered the study. Those who rated themselves as successful without belonging to the general staff were more satisfied with their life $(M=5.88)$ than the other group $(M=4.23 ; t(25)=4.14, p<0.001 ; d=1.56)$.

\section{Discussion}

This is the first study to report data on orientations to happiness in a military context. The findings underline the usefulness of variables from positive psychology in this area. Among Swiss career officers, three orientations to happiness (i.e., life of pleasure, life of engagement, and life of meaning) were positively related to satisfaction with life. However the coefficients were rather low $\left(r^{2}\right.$ were between .02 and .04$)$, indicating that there is a relation but that there is no strong direct relation to the well-being of a person. Coefficients for overall work satisfaction were lower and only the meaningful life seemed to contribute to its expression. The strongest relation in this area suggests that those who lead an engaged life are also more satisfied with the content-related aspects of their work $\left(r^{2}=0.08\right)$. Thus, those who are satisfied with the diversity of the requirements of their job, who have a higher interest in what they are doing, who identify with the tasks or who have higher autonomy in what they are doing also display a higher endorsement to the engaged life. The latter is related to Csikszentmihalyi's (1990) concept of flow. Additionally conducted regression analyses help break down the results to a main statement; i.e., satisfaction with life in Swiss Armed Forces Officers is predicted by an engaged life, while the meaningful life predicts satisfaction with work.

These findings may encourage the development of a customized training program for military officers. Improving their abilities to identify and to use their own strengths may positively impact their personal and vocational growth. It certainly carries the potential to be a strategy for enhancing both life- and work satisfaction. Pending further support for the conclusions and findings, one might argue that a focus on orientations to happiness may also become an integral part of a training module for future career officers. The creation of an inspiring, active and accountable working environment would need to be given high priority. Communication has to be interactive across both groups of people, research and HR. This includes a verifying dialogue with the administrative professionals. Overall, one might argue that strategies for fostering engagement and meaning could be helpful for substantiating coaching approaches for improving the satisfaction with work among career officers. This could also be accompanied by interventions targeting character strengths (Peterson and Seligman 2004), in the sense that the knowledge of one's signature strengths and their application in daily life might be a key to increased well-being (cf. Proctor et al. 2011; Seligman et al. 2005).

It is noticeable that the intercorrelations of the pleasurable and the meaningful life are higher among the career officers than what was reported in other samples collected in the

Footnote 2 continued

comparable results. Most notably, the meaningful life $(r=-0.17, p<0.05)$ and the content-related aspects of work $(r=-0.22, p<0.01)$ were related to being a member of the general staff. 
German-language area (e.g., Peterson et al., 2005; Proyer et al. in press; Ruch et al. 2010). This might indicate that officers are more able to combine pleasurable with meaningful aspects of their work. However, this comparably high relation should be examined in future studies more deeply as it cannot fully be explained with the present data. Overall, this seems to be a characteristic of that specific job as higher meaning and pleasure are usually the orientations with the lowest intercorrelation. It is up to future studies to determine whether this might be related to the specific selection procedure that all officers underwent or whether other explanations might be plausible. It is known that a military organization creates a value-based environment. Career officers learn to achieve higher satisfaction levels and learn to adapt more effectively to challenging situations. They also develop a sense of existential meaning, which appears to relate to a military occupation (see Bartone 2005).

In the present study, satisfaction with life and work were highest among those participants who had the highest self-reported success in their career. This was also well reflected regarding the content-related aspects of work. Furthermore, they seemed to experience less resignative aspects of their work. One of the most interesting results of these comparisons was that the successful career officers endorsed the engaged and the meaningful life to a higher degree. These are the orientations to happiness that seem to be related highest to satisfaction with life (see Peterson et al. 2005; Peterson et al. 2007). However, the present results suggest that self-perceived career success is also related to being absorbed by engaging activities and to using one's own strengths and talents for a higher purpose. As a more objective criterion of career success, we also considered belonging to general staff as an indicator. Participants who were members of the general staff were found to have higher work satisfaction, to be more satisfied with content-related aspects of their work and to be higher in their endorsements of the engaged and the meaningful life. Overall, the results converged well despite the satisfaction with life. It seems as if perceived engagement and meaning are stable contributors to satisfaction with work and career success and selfestimated satisfaction with life.

Finally, the role of the Armed Forces in Switzerland and its position in the society need to be discussed shortly. As already mentioned in the introductory section, there is an ongoing political and public discussion of the tasks of the Army in Switzerland. This led to some uncertainty in the members of the Swiss Army (e.g., about the requirements that need to be fulfilled) and, of course, among the professionals. Furthermore, there seems to be a tendency to experience working conditions worse than compared to those at the time before the major Army reforms in 1995 and 2004. Aspects that are frequently mentioned are the wages, arrangements for expenses, regulations for company vehicles, organizational management style or restrictions of career options. This comparison relates to a higher emotional load among the personnel as Gutknecht and Krautz (2004) demonstrated. From the viewpoint of the Army personnel, these effects cannot be compensated by external factors such as comparatively high wages or high(er) job security (compared to the private sector). Thus, one might assume that those who stay in the Army are highly aware of their working conditions. They intrinsically engage in their tasks, which further allow them to experience meaning. Whether this should be interpreted within a framework of dissonance theory (see Festinger 1957; e.g., in the sense of effort justification for the demands and characteristics of the job) or in a different way (e.g., in terms of dealing with reality constraints when interacting with ones environment that might have an impact on perceptual processes that influence well-being; cf. Tesser's attitude polarization, 1978) is a topic for future studies. 
As a limitation of the study, it has to be mentioned that we had a response rate of about half of those who were initially invited to participate. There might be selection effects in the sense that only those participated that were more satisfied with their work or life. Additionally, we used a cross-sectional design and, hence, results should be interpreted with caution and need to be replicated. Except for the information on the membership in the general staff, all data used in this study were self-report data. Thus, they might be biased in different ways (e.g., by answer distortions, socially desirable answers, etc.). As pointed out earlier, the Swiss Armed Forces are viewed critical in the public perception and this might, of course, also have had an influence on the answer behavior of the participants. Finally, we were unable to differentiate between Land Forces and Air Force. However, as education, selection, training, and vocational duties are rather similar for the officers in the Army, we assume that the results do not differ strongly between them-this, however, needs to be tested empirically.

\section{References}

Allen, N. J. (2003). Organizational commitment in the military: A discussion of theory and practice. Military Psychology. doi:10.1207/S15327876MP1503_06.

Annen, H. (2004). Personnel marketing in turbulent times. Recruitment and retention activities for military personnel in the Swiss Army. Paper presented at the 46th Annual conference of the International Military Testing Association [Online]. Available: http://www.internationalmta.org/Documents/2004/ 2004055P.pdf (Retrieved on January 2011).

Annen, H., Seiler, S., \& Jonas, K. (2010). Military Psychology in Switzerland [Special issue]. Swiss Journal of Psychology, 69(2).

Annen, H., Steiger, R., \& Zwygart, U. (2004). Gemeinsam zum Ziel. Anregungen für Führungskräfte einer modernen Armee [Together towards the goal. Suggestions for managers in a modern army]. Frauenfeld, Switzerland: Huber.

Bartone, P. T. (2005). The need for positive meaning in military operations. Reflections on Abu Ghraib. Military Psychology. doi:10.1207/s15327876mp1704_5.

Chen, L. H., Tsai, Y. M., \& Chen, M. Y. (2010). Psychometric analysis of the Orientations to Happiness Questionnaire in Taiwanese undergraduate students. Social Indicators Research. doi:10.1007/ s11205-009-9473-2.

Coyne, I., \& Bartram, D. (2006). ITC guidelines on computer-based and Internet-delivered testing [Special Issue]. International Journal of Testing, 6(2).

Csikszentmihalyi, M. (1990). Flow: The psychology of optimal experience. New York: HarperCollins.

Csikszentmihalyi, M., \& LeFevre, J. (1989). Optimal experience in work and leisure. Journal of Personality and Social Psychology, 56, 815-822. doi:10.1037/0022-3514.56.5.815.

Diener, E. (1994). Assessing subjective well-being: Progress and opportunities. Social Indicators Research. doi:10.1007/BF01207052.

Diener, E., Emmons, R. A., Larsen, R. J., \& Griffin, S. (1985). The Satisfaction with Life Scale. Journal of Personality Assessment. doi:10.1207/s15327752jpa4901_13.

Diener, E., Nappa-Scollon, C. J., Oishi, S., Dzokoto, V., \& Suh, E. M. (2000). Positivity and the construction of life satisfaction judgments: Global happiness is not the sum of its parts. Journal of Happiness Studies. doi:10.1007/978-90-481-2352-0_11.

Eisenberger, R., Jones, J. R., Stinglhamber, F., Shanock, L., \& Randall, A. T. (2005). Flow experiences at work: For high need achievers alone? Journal of Organizational Behavior. doi:10.1002/job.337.

Festinger, L. (1957). A theory of cognitive dissonance. Evanston, Ill: Row Peterson.

Fullagar, C. J., \& Kelloway, E. K. (2009). 'Flow' at work: An experience sampling approach. Journal of Occupational and Organizational Psychology. doi:10.1348/096317908X357903.

Gosling, S. D., Vazire, S., Srivastava, S., \& John, O. P. (2004). Should we trust web-based studies? A comparative analysis of six preconceptions about Internet questionnaires. American Psychologist. doi: 10.1037/0003-066X.59.2.93.

Gutknecht, S. P. (2007). Arbeitszufriedenheit und Commitment in Zeiten organisationalen Wandels: Zum Einfluss von Persönlichkeitsmerkmalen auf organisationsspezifische Einstellungen - eine Untersuchung in Militär und Wirtschaft [Job satisfaction and commitment during organizational change: 
influence of personality traits on attitudes towards organizations - a military and economic study]. Saarbrücken, Germany: VDM.

Gutknecht, S. P., \& Krautz, A. (2004). Organisationsspezifische Einstellungen Schweizer Berufsmilitärs [Organization-specific convictions of professional Swiss military personnel]. ASMZ, 3, 24-26.

Gutknecht, S. P., Semmer, N. K., \& Annen, H. (2005). Prognostische Validität eines Assessment Centers für den Studien- und Berufserfolg von Berufsoffizieren der Schweizer Armee [Predictive validity of an assessment center for the study and professional success of career officers in the Swiss Army]. Zeitschrift für Personalpsychologie. doi:10.1026/1617-6391.4.4.170.

Hackman, J. R., \& Oldham, G. R. (1980). Work redesign. Reading, MA: Addison-Wesley.

Hindelang, R. L., Schwerin, M. J., \& Farmer, W. L. (2004). Quality of Life (QOL) in the U.S. Marine Corps: The validation of a QOL Model for predicting reenlistment intentions. Military Psychology. doi: 10.1207/S15327876MP1602_3.

Matthews, M. D., Eid, J., Kelly, D., Bailey, J. K. S., \& Peterson, C. (2008). Toward a positive military psychology. Military Psychology. doi:10.1080/08995600802345246.

Nielsen, K., \& Cleal, B. (2010). Predicting flow at work: Investigating the activities and job characteristics that predict flow states at work. Journal of Occupational Health Psychology. doi:10.1037/a0018893.

Park, N., Peterson, C., \& Ruch, W. (2009). Orientations to happiness and life satisfaction in twenty-seven nations. The Journal of Positive Psychology. doi:10.1080/17439760902933690.

Peterson, C., Park, N., \& Seligman, M. E. P. (2005). Orientations to happiness and life satisfaction: The full versus the empty life. Journal of Happiness Studies. doi:10.1007/s10902-004-1278-Z.

Peterson, C., Ruch, W., Beermann, U., Park, N., \& Seligman, M. E. P. (2007). Strengths of character, orientations to happiness, and life satisfaction. The Journal of Positive Psychology. doi:10.1080/ 17439760701228938.

Peterson, C., \& Seligman, M. E. P. (2004). Character strengths and virtues: A handbook and classification. Washington, DC: American Psychological Association.

Proctor, C., Matlby, J., \& Linley, A. P. (2011). Strengths use as a predictor of well-being and health related quality of life. Journal of Happiness Studies, 12, 153-169. doi:10.1007/s10902-009-9181-2.

Proyer, R. T., Ruch, W., \& Chen, G. (in press). Positive psychology and the fear of being laughed at: Gelotophobia and its relations to orientations to happiness and life satisfaction in Austria, China, and Switzerland. Humor: International Journal of Humor Research.

Ruch, W., Harzer, C., Proyer, R. T., Park, N., \& Peterson, C. (2010a). Ways to happiness in Germanspeaking countries: The adaptation of the German version of the Orientations to Happiness Questionnaire in paper-pencil and internet samples. European Journal of Psychological Assessment. doi: 10.1027/1015-5759/a000030.

Ruch, W., Proyer, R. T., Harzer, C, Park, N., Peterson, C., \& Seligman, M. E. P. (2010b). Adaptation and Validation of the German Version of the Values in Action Inventory of Strengths (VIA-IS) and the Development of a Peer-Rating Form. Journal of Individual Differences. doi:10.1027/1614-0001/ $\mathrm{a} 000022$.

Ryan, R.M., \& Deci, E.L. (2001). On happiness and human potentials: A review of research on hedonic and eudaimonic well-being. Annual Review of Psychology. doi:10.1146/annurev.psych.52.1.141.

Sanchez, R. P., Bray, R. M., Vincus, A. A., \& Bann, C. M. (2004). Predictors of job satisfaction among active duty and reserve/guard personnel in the U.S. Military. Military Psychology. doi:10.1207/ s15327876mp1601_2.

Schueller, S. M., \& Seligman, M. E. P. (2010). Pursuit of pleasure, engagement, and meaning: Relationships to subjective and objective measures of well-being. The Journal of Positive Psychology. doi: $10.1080 / 17439761003794130$.

Schweizer Armee (2004). Dienstreglement 04 der Schweizer Armee [Service regulations of the Swiss Army]. Switzerland: Author.

Seligman, M. E. P. (2002). Authentic happiness. New York: Free Press.

Seligman, M. E. P., \& Csikszentmihalyi, M. (2000). Positive psychology: An introduction. American Psychologist. doi:10.1037//0003-066X.55.1.5.

Seligman, M. E. P., Steen, T., Park, N., \& Peterson, C. (2005). Positive psychology progress: Empirical validation of interventions. American Psychologist, 60, 410-421. doi:10.1037/0003-066X.60.5.410.

Sheldon, K. M. (2002). The self-concordance model of healthy goal striving: When personal goals correctly represent the person. In E. L. Deci \& R. M. Ryan (Eds.), Handbook of self-determination research (pp. 65-86). Rochester, NY: University of Rochester Press.

Tesser, A. (1978). Self-generated attitude change. In L. Berkowitz (Ed.), Advances in experimental social psychology (Vol. 11, pp. 289-338). San Diego, CA: Academic Press.

van Dick, R., Schnitger, C., Schwartzmann-Buchelt, C., \& Wagner, U. (2001). Der Job Diagnostic Survey im Bildungsbereich: Eine Überprüfung der Gültigkeit des Job Characteristics Model bei Lehrerinnen 
und Lehrern, Hochschulangehörigen und Erzieherinnen mit berufsspezifischen Weiterentwicklungen des JDS [The Job Diagnostic Survey (JDS) for educational sector occupations: An evaluation of model properties of the Job Characteristic Model among teachers, university staff members, and nursery school teachers with job-specific versions of the JDS]. Zeitschrift für Arbeits- und Organisationspsychologie. doi:10.1026//0932-4089.45.2.74.

Vella-Brodrick, D. A., Park, N., \& Peterson, C. (2009). Three ways to be happy: Pleasure, engagement, and meaning: Findings from Australian and US samples. Social Indicators Research. doi:10.1007/s11205008-9251-6.

Wilcove, G. L., Schwerin, M. J., \& Wolosin, D. G. (2003). An exploratory model of quality of life in the U.S. Navy. Military Psychology, 15, 133-152. doi:10.1207/S15327876MP1502_3. 